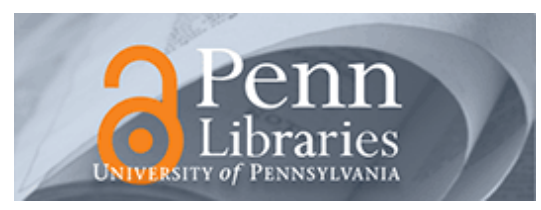

Manuscript Studies

Volume 2

Issue 2 Fall 2017

Article 4

2018

\title{
"My Written Books of Surgery in the Englishe Tonge": The London Company of Barber-Surgeons and the Lylye of Medicynes
}

Erin Connelly

University of Pennsylvania, erincon@upenn.edu

Follow this and additional works at: https://repository.upenn.edu/mss_sims

Part of the European History Commons, History of Science, Technology, and Medicine Commons, and the Medieval Studies Commons

\section{Recommended Citation}

Connelly, Erin (2018) "'My Written Books of Surgery in the Englishe Tonge": The London Company of Barber-Surgeons and the Lylye of Medicynes," Manuscript Studies: Vol. 2 : Iss. 2 , Article 4.

Available at: https://repository.upenn.edu/mss_sims/vol2/iss2/4

This paper is posted at ScholarlyCommons. https://repository.upenn.edu/mss_sims/vol2/iss2/4

For more information, please contact repository@pobox.upenn.edu. 


\title{
"My Written Books of Surgery in the Englishe Tonge": The London Company of Barber-Surgeons and the Lylye of Medicynes
}

\author{
Abstract \\ The Middle English Lylye of Medicynes is an early fifteenth-century translation of Bernard of Gordon's \\ Latin Lilium medicinae (completed in 1305). The Lylye is contained in Oxford Bodleian Library MS. \\ Ashmole 1505 as a sole text. Although there are many extant witnesses in Latin, there are no other known \\ Middle English copies. The Lylye contains thousands of medicinal ingredients, including 360 individual \\ recipes identified with $\mathrm{Rx}$, with accompanying guidelines for diagnosis and prognosis. Although the text \\ does contain some medical theory and etiology (based on thought from Arabic medicine, specifically Ibn \\ Sinā, and Antiquity, predominantly Galen and Hippocrates), its main feature is the large volume of \\ medicinal recipes. It is thought to have been commissioned by Robert Broke, 'master of the king's \\ stillatories,' in the early fifteenth century during the reign of Henry VI. This article explores the later \\ provenance of the Lylye amongst the Gale family of barber-surgeons in sixteenth-century London.
}

\section{Keywords}

barber-surgeon; provenance; medieval medicine; Middle English; Robert Broke; Thomas Gale; William Gale; Bernard of Gordon; Lilium medicinae; Lylye of Medicynes 


\section{MANUSCRIPT STUDIES \\ A Journal of the Schoenberg Institute for Manuscript Studies}

VOLUME 2, NUMBER 2

(Fall 2017)

Manuscript Studies (ISSN 2381-5329) is published semiannually

by the University of Pennsylvania Press

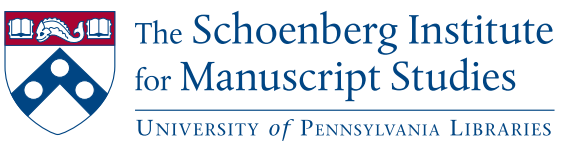




\section{MANUSCRIPT STUDIES}

VOLUME 2, N UMBER 2

(Fall 2017)

\section{ISSN 2381-5329}

Copyright (C) 2017 University of Pennsylvania Libraries and University of Pennsylvania Press. All rights reserved.

Published by the University of Pennsylvania Press, 3905 Spruce Street, Philadelphia, PA 19104.

Printed in the U.S.A. on acid-free paper.

Manuscript Studies brings together scholarship from around the world and across disciplines related to the study of premodern manuscript books and documents, with a special emphasis on the role of digital technologies in advancing manuscript research. Articles for submission should be prepared according to the Chicago Manual of Style, $16^{\text {th }}$ edition, and follow the style guidelines found at http://mss.pennpress.org.

None of the contents of this journal may be reproduced without prior written consent of the University of Pennsylvania Press. Authorization to photocopy is granted by the University of Pennsylvania Press for libraries or other users registered with Copyright Clearance Center (CCC) Transaction Reporting Service, provided that all required fees are verified with CCC and paid directly to CCC, 222 Rosewood Drive, Danvers, MA 01923. This consent does not extend to other kinds of copying for general distribution, for advertising or promotional purposes, for creating new collective works, for database retrieval, or for resale.

\section{SUBSCRIPTION INFORMATION:}

Single issues: $\$ 30$

Print and online subscriptions: Individuals: \$40; Institutions: \$90; Full-time Students: \$30 International subscribers, please add $\$ 18$ per year for shipping.

Online-only subscriptions: Individuals: \$32; Institutions: \$78

Please direct all subscription orders, inquiries, requests for single issues, address changes, and other business communications to Penn Press Journals, 3905 Spruce Street, Philadelphia, PA 19104. Phone: 215-573-1295. Fax: 215-746-3636. Email: journals@pobox.upenn.edu. Prepayment is required. Orders may be charged to MasterCard, Visa, and American Express credit cards. Checks and money orders should be made payable to "University of Pennsylvania Press" and sent to the address printed directly above.

One-year subscriptions are valid January 1 through December 31. Subscriptions received after October 31 in any year become effective the following January 1 . Subscribers joining midyear receive immediately copies of all issues of Manuscript Studies already in print for that year.

Postmaster: send address changes to Penn Press Journals, 3905 Spruce Street, Philadelphia, PA 19104.

Visit Manuscript Studies on the web at mss.pennpress.org. 
Connelly: "My Written Books of Surgery in the Englishe Tonge": The London C

\section{MANUSCRIPT STUDIES}

A Journal of the Schoenberg Institute for Manuscript Studies

V OL U M 2, N U M B R 2

\section{Articles}

Statim Prosequi: An Index as a Product, Instrument, and Medium of the Medieval Franciscan Inquisition in Tuscany

Geoffrey W. Clement

A Tool for Exemplary Pastoral Care: Three Booklets of the

Edwardes Manuscript in Context

HANNAH WeAVER

Conversational Lollardy: Reading the Margins of

MS Bodley 978

Elizabeth SCHIRMer

"My Written Books of Surgery in the Englishe Tonge":

The London Company of Barber-Surgeons and the Lylye of Medicynes

ERIN CONNELLY

The Two Yohannases of Santo Stefano degli Abissini, Rome: Reconstructing Biography and Cross-Cultural Encounter through Manuscript Evidence

Samantha Kelly and Denis Nosnitsin

Textual Contents of Pāli Samut Khois: In Connection with the Buddha's Abhidhamma Teaching in Tāvatiṃsa Heaven Toshiya Unebe

The Western Manuscript Collection of Alfred Chester Beatty (ca. 1915-1930) 
Manuscript Studies, Vol. 2 [2018], Iss. 2, Art. 4

iv | Journal for Manuscript Studies

The St. Chad Gospels: Diachronic Manuscript Registration and Visualization

Stephen Parsons, C. Seth Parker, and W. Brent Seales

\section{Annotations}

An Investigation of the Relationship between Prince Shōtoku's Shōmangyō-gisho and Two Dunhuang Buddhist Manuscripts: A Debate over Originality and Canonical Value Mark Dennis

The Glossa Ordinaria Manuscripts of the Biblioteca Capitolare of Monza

E. ANn MatTer 508

The Summula de Summa Raymundi in Gordan MS 95, Bryn Mawr College

Tномаs IzBicki 524

A Newly Discovered Manuscript of the Historia de los Reyes Moros de Granada by Hernando de Baeza

María Mercedes Delgado Pérez 540

\section{Reviews}

Albert Derolez. The Making and Meaning of the Liber Floridus: A Study of the Original Manuscript, Ghent, University Library MS 92

Mary FrankLin-Brown 569

Bent Lerbæk Pedersen. Catalogue of Yao Manuscripts ADAm SMith

T. L. Andrews and C. Macé, eds. Analysis of Ancient and Medieval Texts and Manuscripts: Digital Approaches 
Connelly: "My Written Books of Surgery in the Englishe Tonge": The London C Contents | v

Elizabeth Solopova. Manuscripts of the Wycliffite Bible in the Bodleian and Oxford College Libraries

KathleEn Kennedy

Colour: The Art and Science of Illuminated Manuscripts

Nicholas Herman

List of Manuscripts Cited 


\title{
"My Written Books of Surgery in the Englishe Tonge" \\ The London Company of Barber-Surgeons and the Lylye of Medicynes
}

\author{
ERIN ConNelly \\ University of Pennsylvania
}

I

N His Will of 1567, Thomas Gale, a leading member and one-time master of the Company of Barber-Surgeons, bequeathed to William Gale, also a prominent barber-surgeon (and twice master), all of his surgical books, papers, and examinations written in English. An ownership inscription containing the name "William Gale, surgeon," written in bold block capitals in folio 1 of the Lylye of Medicynes, may indicate a connection with Thomas Gale's collection. This premise will be considered in light of extant evidence following a brief introduction to the Lylye and other owners.

The Middle English Lylye is an early fifteenth-century translation of Bernard of Gordon's Lilium medicinae (completed in 1305). The Lylye is contained in Oxford Bodleian Library MS Ashmole 1505 as a sole text in 245 folios (fols. $4 \mathrm{r}$ to $244 \mathrm{v}$ contain text). There are several extant witnesses in Latin, but there are no other known Middle English copies of this text. Although the text does contain some medical theory and etiology (based on thought from Arabic medicine, specifically Ibn Sīnā, and antiquity, predominantly Galen and Hippocrates), its main feature is the large volume of medicinal recipes for practical use. There are four names that appear in the 
first and final folios of the manuscript in connection with provenance: Robert Broke, Richard Cler, William Gale, and Blanche May. The following will briefly review what has been uncovered previously about the two earliest owners (Robert Broke and Richard Cler) and then will present in greater detail how the manuscript is connected with the sixteenth-century London Company of Barber-Surgeons, which, to present knowledge, has not been discussed previously.

\section{Ownership Inscriptions}

The introduction to the Lylye states that after twenty years of medical practice, Bernard of Gordon began to write "a boke of practyk" for "meke men" from his study in Montpellier (fol. 4r). While Bernard may have originally intended the Lilium medicinae for physicians in training, it has been suggested by Linda Voigts and Luke Demaitre that the Middle English translation in Ashmole 1505 belongs more to the "apothecary's world," which is connected with an inscription in the final folio of the manuscript: "Master Broke, master of the kyngis styllatorys and maker of hys excellent wateris" (figure 1). ${ }^{1}$ The manuscript does not contain illustrations, except for two portraits in the bottom margin of folio 4r. The portrait of Robert Broke (also Brock, Brook, or Brooke) appears next to an author portrait of Bernard, labeled as Bernardus auctor, who is standing next to a lily plant (figure 2). Bernard holds a scroll that states: "Ecce nomen huius libri" (Behold, the name of this book). The figure notated as Brock holds a scroll stating: "Benedicat illum deus qui composuit librum hunc" (God bless him who wrote this book). The name has caused some confusion in the past. Edward Bernard's 1697 account of the manuscript states that the text was "Bernard Brook's Treatise of Physick in 7 books.” ${ }^{2}$ W. H. Black's catalogue in 1845 attributed the error to the sixteenth-century owner, William Gale, who

1 Luke Demaitre, “Translations of Bernard of Gordon's Lilium medicinae, 'A booke practike to meke men'?" (unpublished article, personal communication, September 2011), 25.

2 Edward Bernard, Catalogi Librorum Manuscriptorum Angliae et Hiberniae (Oxford: Theatro Sheldoniano, 1697), 341. 
Manuscript Studies, Vol. 2 [2018], Iss. 2, Art. 4

Connelly, "My Written Books of Surgery in the Englishe Tonge"

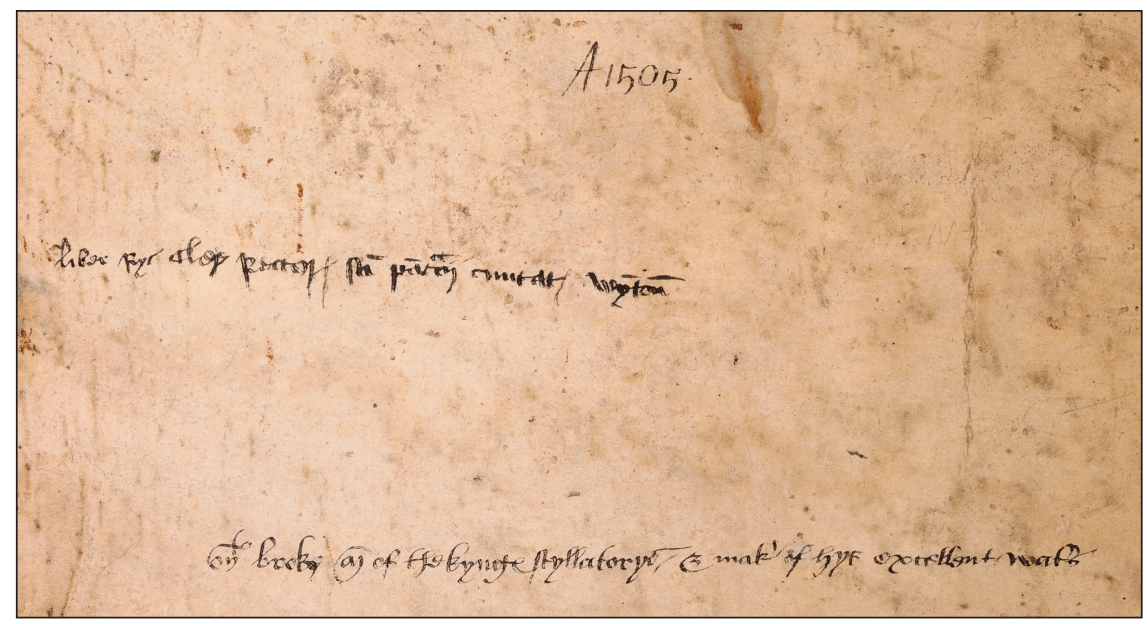

FIGURE 1. Detail of ownership inscriptions, Oxford, Bodleian Library, MS Ashmole 1505 , fol. 245r.

likely wrote Bernardus Brooke on folio 2r. ${ }^{3}$ Linda Voigts has connected the name in the Lylye with the fifteenth-century distiller Robert Broke, who was "Master of the King's Stillatories" during the reign of Henry VI. ${ }^{4}$

Folio $245 \mathrm{r}$ contains the ownership inscription pertaining to Broke, and another stating: "Liber Ryc cler rectoris sancti pancracij civitatis wynton" (figure 1). This inscription refers to Richard Cler, rector of St. Pancras, Winchester, who was admitted to Oxford in 1460, became a fellow of New College in 1466, and was promoted to a benefice in $1472 .{ }^{5}$ Otto Pächt and J. J. G. Alexander identify Cler as the first owner and state that Broke is "perhaps an owner." ${ }^{6}$ However, it is more likely that Robert Broke, member of the king's household and distiller, was the first owner of the manuscript.

3 W. H. Black, A Descriptive Analytical and Critical Catalogue of the Manuscripts Bequeathed unto the University of Oxford by Elias Asbmole (Oxford: Oxford University Press, 1845), 1407. 4 Linda Voigts, "The Master of the King's Stillatories," in The Lancastrian Court: Proceedings of the 2001 Harlaxton Symposium, Harlaxton Medieval Studies 13, ed. Jenny Stratford (Donington, Lincs.: Shaun Tyas, 2003), 233-52.

5 Voigts, “The Master of the King's Stillatories," 235.

6 Otto Pächt and J. J. G. Alexander, eds., Illuminated Manuscripts in the Bodleian Library, Oxford, vol. 3: British, Irish and Icelandic Schools (Oxford: Oxford University Press, 1973), 77. 


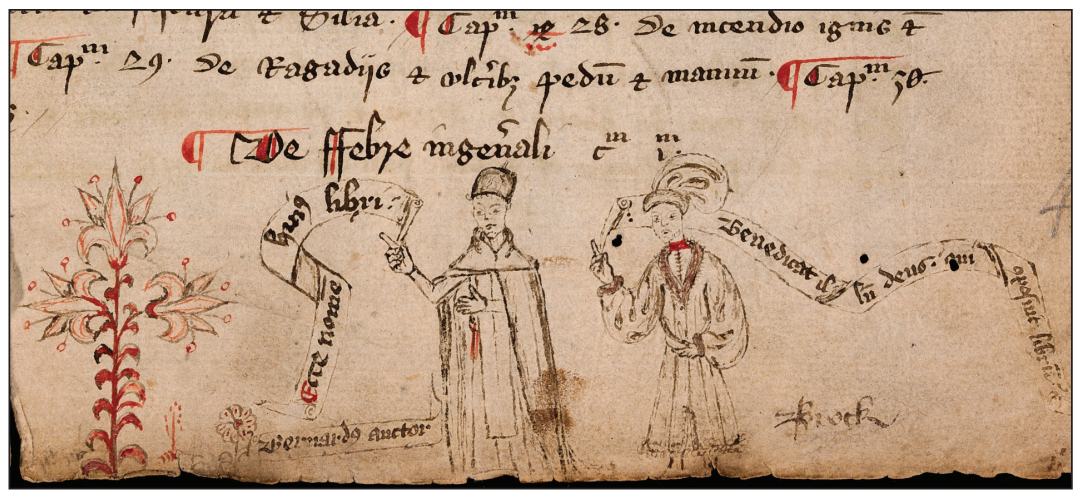

FIGURE 2. Detail of illustration, Oxford, Bodleian Library, MS Ashmole 1505, fol. 4r.

Kathleen Scott, an expert in medieval costume, states that the clothing worn in the portraits of Bernard and Broke "is datable probably after 1425 and before 1450." An examination of documentary evidence in regard to Robert Broke, researched by Voigts, provides support for this date range, with the name first appearing in the records in 1425 and disappearing after $1455 .{ }^{8}$ Voigts has identified Cler as "presumably the cleric from Crondall in Hampshire" and suggested that Broke may also have an association with Winchester. ${ }^{9}$ Furthermore, the text of the Lylye is written in a Hampshire dialect. However, aside from these circumstantial connections with Hampshire, it is not clear how Broke and Cler may be associated or how the manuscript passed between them.

Along with the ownership inscriptions of Robert Broke and Richard Cler, there are notations in the first folios of the manuscript connected with later owners. On the left edge of folio $1 \mathrm{v}$ is written: "Blanc[h]e may was married the ix day of Julye in the yere of oure lorde 1567 WG" (figure 3). On the same folio, the date 1578 is written on the top of the page above: "Pre-

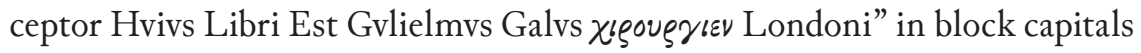
(figure 4). The date 1578 is also written on the top of folio $245 \mathrm{r}$ above the

7 Voigts, "The Master of the King's Stillatories," 235.

8 Voigts, "The Master of the King's Stillatories," 233-37.

9 Voigts, "The Master of the King's Stillatories," 235, 241. 
Manuscript Studies, Vol. 2 [2018], Iss. 2, Art. 4

Connelly, "My Written Books of Surgery in the Englishe Tonge" | 373

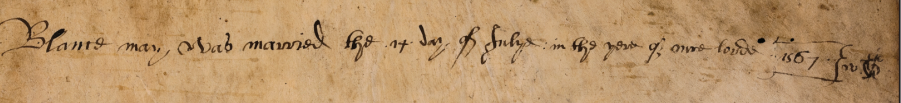

FIGURE 3. Detail of ownership inscription, Oxford, Bodleian Library, MS Ashmole 1505 , fol. 1v.

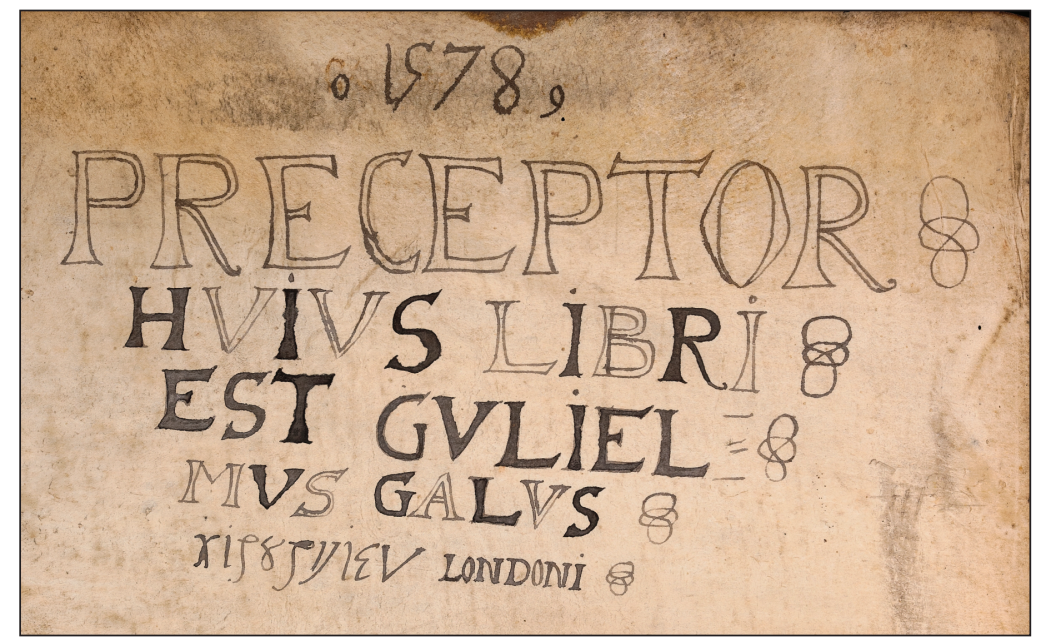

FIGURE 4. Detail of ownership inscription, Oxford, Bodleian Library, MS

Ashmole 1505, fol. 1v.

inscriptions for Broke and Cler. On folio 2r, the date 1303 is written above: "Barnardvs Brooke Est Avctor Hvivs Libri 1303" in block capitals by the same hand as folio 1v (figure 5). The date of 1578 and description of William

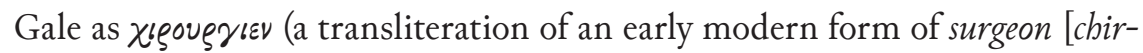
ourgien] into Greek letters) is evidence that this inscription is from the William Gale connected with the Company of Barber-Surgeons..$^{10}$ Using the inscription on folio $1 \mathrm{v}$ as a starting point, the following section will investigate the appearance of members of the Gale family in available sixteenth-century records and explore what can be deduced about their relationships to each other and, crucially, to Ashmole 1505.

10 Many thanks to Bruce Barker-Benfield (Medieval Manuscripts Curator, Weston Library) for his assistance in reading this word. The responsibility for the conclusions here is my own. 


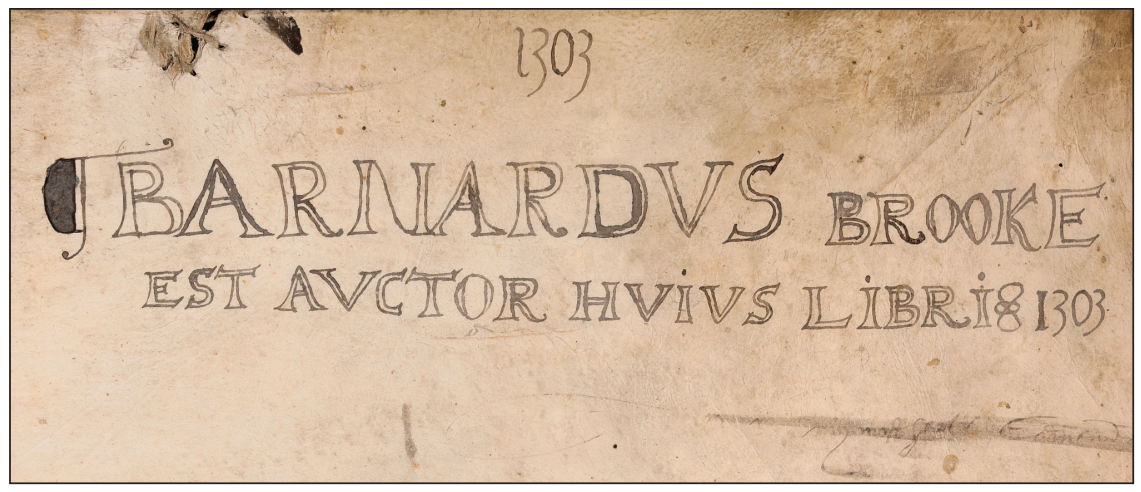

FIGURE 5. Detail of inscription, Oxford Bodleian Library, MS Ashmole 1505, fol. 2r.

\section{Documentary Evidence}

Thomas Gale (1) appears in the Barber-Surgeons' list of wardens and masters in 1546 (warden), 1555 (warden), and 1561 (master). ${ }^{11}$ It is likely that he was a member of the company from its inception by an act of Parliament in 1540 , as he was already practicing in London by the 1520 s. He is noted for his publication Certaine Workes of Chirurgerie (1563), which is divided into four books (Institution of Chirurgerie, Enchiridion, a treatise on gunshot wounds, and an Antidotarie). In his treatise on gunshot wounds, Gale relates the case study of a patient he treated in London who was injured during the Siege of Pavia (1524-25) when he "fyrste practised the arte of chirurgerye," which indicates that he was practicing in London by his early twenties. ${ }^{12}$ In the same treatise, Gale records that he also served as a surgeon under Henry VIII at the Siege of Montreuil (1544), and under Philip II of Spain in the Battle of St. Quentin (1557). ${ }^{13}$

11 From this point, different individuals of the Gale family sharing the same name will be numbered in places where confusion may occur; Sidney Young, The Annals of the BarberSurgeons of London (London: Blades, East \& Blades, 1890), 5-6.

12 Thomas Gale, Certaine Workes of Chirurgerie (London: Rouland Hall, 1563), Boston Medical Library Collection, www.archive.org, accessed February 2016 (Treatise on Gunshot Wounds), fol. 16r.

13 Gale, Certaine Workes of Chirurgerie (Treatise on Gunshot Wounds), fol. 16r. 
He also produced a translation of Galen's Methodus medendi (1566) for non-Latinate students and made reference to plans for other works, which were cut short by his death in $1567 .{ }^{14}$ There has been some discrepancy about his date of death, with many publications listing it as 1586/7; however, his will is dated “the fyrste Daye of August 1567," it was probated 27 August 1567, and his burial at St. Dionis Backchurch on 15 August 1567 is recorded in the church register as "Thomas Gale, householder and surgeon." 15

In his will, Thomas Gale describes himself as a "barbour surgion of London" and gives instructions to the "masters of our Company of Barbour Surgions" to bear him to St. Dionis Backchurch after his death. He refers to two brothers, William Gale and Roger Gale, to whom he bequeaths $£ 4$. Significantly, another William Gale (1), referred to as a "late servant," receives all of his surgical books:

I gyve and bequethe unto William Gale my late servant all my written books of surgery in the Englishe tonge and all the pamflitts and peces of written books or any written books of surgery wherein any Englishe is written, bundells of examinations, etc. to be delivered unto him within conveniente time after my decease. ${ }^{16}$

14 Gale, Certaine Workes of Chirurgerie (Epistle Dedicatorie); see also Päivi Pahta, Turo Hiltunen, Ville Marttila, Maura Ratia, Carla Suhr, and Jukka Tyrkkö, "Communicating Galen's Methodus medendi in Middle and Early Modern English," in Communicating Early English Manuscripts, ed. Päivi Pahta and Andreas H. Jucker (Cambridge: Cambridge University Press, 2011), 181-2.

15 The date range of 1507-87 appears to be linked to an entry in an early edition of the Dictionary of National Biography (1921-22, 7:818). The Oxford Dictionary of National Biography $(O D N B)$ has since been updated to c. 1507-67. Note the entry in the ODNB states that the will was made on "6 August," which should be "first of August"; The National ArchivesPrerogative Court of Canterbury, PROB 11/49/251, Will of Thomas Gale, Barber-Surgeon of London, 27 August 1567, http://discovery.nationalarchives.gov.uk/details/r/D957287; Joseph Lemuel Chester, The Reiester Booke of Saynte De'nis, Backchurch Parishe (City of London) for Maryages, Christenyges, and Buryalles, Begynnynge in the Yeare of Our Lord God 1538 (London: Mitchell and Hughes, 1878), 190, www.archive.org, accessed February 2016.

16 The National Archives-Prerogative Court of Canterbury, PROB 11/49/251. 
In the Register of Admissions to the Company of Barber-Surgeons, a William Gale (Gayle) (1) is listed as an apprentice of Thomas Gale (Gayle) (1), and he was admitted to the company on 1 October 1566, which means that he completed his apprenticeship in time to be referred to as a former servant by Thomas Gale (1). ${ }^{17}$ There is evidence in the register of only one William Gale admitted to the company up until 5 July 1687. He was a warden of the company in 1583 and 1590, and was elected master in 1595 and 1610, but died on 19 November 1610 at about seventy years old (placing his date of birth around 1540). ${ }^{18} \mathrm{He}$ was buried in St. Mary the Virgin, Monken Hadley.

Furthermore, the barber-surgeons Thomas Gale (1) and William Gale (1) share an association with St. Thomas's Hospital. The hospital was originally located in Southwark and primarily served a large population of London's poor and homeless, as well as women engaged in prostitution. In his Enchiridion, Thomas Gale (1) relates the recipe for a special powder that he invented, in collaboration with Master Peirponte, "chefely for the commonitye of the poore," which was "fyrste put in use and practise by the surgians in Saint Thomas Hospitall in Southworke." ${ }^{19}$ Furthermore, in his Certaine Workes of Galens, called Methodus medendi, he records that in 1562 he examined the conditions of St. Thomas's and St. Bartholomew's Hospitals and found hundreds of patients suffering from severe infections and lack of adequate care due to unregulated practitioners. ${ }^{20}$ The records of St. Thomas's Hospital show that on 28 March 1569, William Gale (1), noted as an "Examiner of Surgeons," succeeded John Brygge as surgeon at St. Thomas's Hospital. In May 1597, the records indicate that a son of William Gale (also called Thomas [2]) appears to have been considered for an

17 Register of Admissions to the Freedom of the Worshipful Company of Barber Surgeons of London, 1522-1664, Guildhall Library MS 5265/1.

18 Young, Annals of the Barber-Surgeons of London, 6-7.

19 Gale, Certaine Workes of Chirurgerie, fol. 56r.

20 Thomas Gale, Certaine Workes of Galens, called Methodus medendi (London: Thomas East, 1586), fol. 32, Early English Books Online, http://name.umdl.umich.edu/A01410 .0001.001, accessed February 2016. 
appointment, which never materialized. ${ }^{21}$ In 1606, one of William Gale's (1) apprentices, Henry Blackley, succeeded him. Similar to Thomas Gale's (1) discussion of treating the poor at St. Thomas's, William Gale's (1) many years of service at a hospital largely devoted to caring for London's less fortunate is reflected in the inscription on his tomb at Monken Hadley: "Blessed are they [that] concydereth [the] poore \& needie."22

Finally, in the seventeenth century, the manuscript was owned by Elias Ashmole. After Ashmole's death, his collection was housed in the Ashmolean Museum and then transferred to the Bodleian Library. The manuscript's journey between the time of Richard Cler to the Gales is uncertain, as is the ownership after William Gale (1). Richard Cler's death has been estimated to have occurred by $1521 / 2$, which was around the time a young Thomas Gale (1) was practicing surgery in London. ${ }^{23}$ In his will, William Gale (1) mentions two of his sons, William (2) and John, of thirteen total children (including his son Thomas Gale [2]). ${ }^{24}$ It is further recorded in the Barber-Surgeons' admissions registers that William Gale (Galle) (1) had an apprentice called Richard Gale (perhaps another son), who was admitted to the company on 10 April 1588. ${ }^{25}$ William (2) is the sole executor of his father's estate, while John received £20. William (2) died at about forty

21 A Thomas Gale was admitted to the Company of Barber-Surgeons 18 January 1596 by patrimony. The $O D N B$ suggests this entry is for a son of Thomas Gale (1). It is perhaps more likely that the entry is synonymous with the son of William Gale (1) who was considered as a possible successor to his father's position at St. Thomas's Hospital; Henry Betham Robinson, "St Thomas's Hospital Surgeons and the Practice of their Art in the Past," in St. Thomas's Hospital Reports, 1901, vol. 28, ed. Hector Mackenzie and G. H. Makins (London: J. \& A. Churchill, 1901; rept. Forgotten Books, vol. 20, 2016 https://www.forgottenbooks.com/en/ books/StThomassHospitalReports_10056485), 416-19, 447; "List of Freemen 1522 to Present," Victoria West, archivist for the Barbers' Company [personal communication, 17 February 2016].

22 Young, Annals of the Barber-Surgeons of London, 574.

23 Pächt and Alexander, Illuminated Manuscripts in the Bodleian Library, vol. 3, 77.

24 The National Archives-Prerogative Court of Canterbury, PROB 11/116/532, Will of William Gale, of Monken Hadley, Middlesex, 21 November 1610, http://discovery.nationalarchives.gov.uk/details/r/D916720.

25 Guildhall Library MS 5265/1. 
years old in 1614 and is buried near his father in Monken Hadley. John Gale is recognized by the Company of Barber-Surgeons for providing funding in his will (1655) for an anatomy lecture called "Gale's Anatomy." 26 The lectureship is now awarded by the Royal College of Surgeons as the Arris and Gale Lectureship. It is considered to be a "highly regarded and prestigious award within the field of surgery." ${ }^{27}$ Perhaps the manuscript went to one of these sons (William [2], John, or Thomas [2]) or remained at the guildhall. Taking into consideration that William Gale (1) was twice master of the guild, it may be possible that the book was used as a display piece or as a part of ceremonies before entering Ashmole's collection.

There is a second possibility for the ownership trail of this manuscript. In his will of 1559 , John Wisdom bequeathed "the Lillie of Medicine in Englishe" to his son Gregory Wisdom. ${ }^{28}$ The Wisdoms began their careers as unlicensed medical practitioners, but they received a royal license in 1542 , and Gregory was admitted to the Royal College of Physicians in 1582 (despite associations with sorcery and fraud). ${ }^{29}$ Gregory's will (1599) does not mention the book. ${ }^{30}$ It is known that Thomas Gale (1) collected books. In addition to the medical texts given to William (1), his will mentions other works, including "my books of Kinge Arthur," which are given to a servant Katherine. ${ }^{31}$ It is possible that Thomas (1), or even William (1), purchased this manuscript copy from Gregory Wisdom in the 1560s. The association of the

26 Young, Annals of the Barber-Surgeons of London, 574, 373.

27 Nuffield Department of Surgical Sciences, "Mr. Jonathan Hyam FHEA DPhil FRCS (Neuro.Surg) has been awarded the Arris \& Gale Lectureship in Physiology by the Royal College of Surgeons of England for 2014," 26 February 2014, www.nds.ox.ac.uk, accessed May 2014; see also I. M. Modlin, “The Surgical Legacy of Arris and Gale," Journal of Medical Biography 4 (1996): 191-99.

28 London Metropolitan Archives, Guildhall Library Register of Wills, MS 9171/15, fol. 99r; Alec Ryrie, The Sorcerer's Tale: Faith and Fraud in Tudor England (Oxford: Oxford University Press, 2008), 53-54, 193.

29 Ryrie, The Sorcerer's Tale, $\mathrm{x}-\mathrm{xi}$.

30 London Metropolitan Archives, Guildhall Library Register of Wills, MS 9051/5, fols. $139 \mathrm{v}-141 \mathrm{r}$.

31 The National Archives-Prerogative Court of Canterbury, PROB 11/49/251. 
Manuscript Studies, Vol. 2 [2018], Iss. 2, Art. 4

Connelly, "My Written Books of Surgery in the Englishe Tonge" | 379

TABLE 1. Estimated Provenance Timeline

\begin{tabular}{lll}
\hline Owner & Birthdate-Deathdate & $\begin{array}{l}\text { First Date of Appearance in } \\
\text { Records }\end{array}$ \\
\hline Robert Broke & d. 1469 & ca. 1425-1455 \\
Richard Cler & d. by $1521 / 2$ & 1460 \\
John Wisdom? & d. 1559 & 1540 s \\
Gregory Wisdom? & d. 1599 & 1540 s \\
Thomas Gale (1) & ca. $1507-1567$ & 1540 s \\
William Gale (1) & ca. $1540-1610$ & 1 October 1566 \\
William Gale (2)? & ca. $1574-1614$ & 21 November 1610 \\
Thomas Gale (2)? & Living 1597 & 18 January 1597 \\
John Gale? & ca. $1585-1655$ & 21 November 1610 \\
Richard Gale? & Living 1588 & 10 April 1588 \\
Elias Ashmole & $1617-1692$ & - \\
Ashmolean Museum & & \\
Bodleian Library & & \\
\hline
\end{tabular}

Wisdoms and Gales will be considered again in the section titled "Relevance of the Lylye of Medicynes" (table 1). ${ }^{32}$

In summary, several Gales appear in the records in relation to each other and to the Company of Barber-Surgeons. While family connections are explicitly stated between William (1) and three of his sons, establishing a familial relationship between William (1) and Thomas (1) is more

32 The Robert Broke 1469 death date is from Voigts, "The Master of the King's Stillatories," 241. 
challenging, as apprentice registers (specifying family connections) for the Company of Barber-Surgeons do not begin until the seventeenth century; likewise, parish records are scarce for the required date range. However, it is possible to piece together some potential links from the available evidence.

As mentioned previously, two William Gales appear in Thomas Gale's (1) will of 1567, a brother and a former servant. It is likely that this former servant, who received all of Thomas Gale's (1) surgical books and examinations, is synonymous with the William Gale (1) listed as his apprentice and admitted to the Company of Barber-Surgeons in 1566. The labels servant and apprentice were used interchangeably in the medieval to early modern period. Although a stronger distinction in the terms began to develop with the Statute of Artificers (1562), this occurred after William Gale's (1) apprenticeship. ${ }^{33}$ Prior to that distinction, in his analysis of Tudor and Stewart towns from 1530 to 1688, Jonathan Barry found that Cambridge lists and wills referenced some individuals as both a servant and an apprentice. ${ }^{34}$ Barry also cites the analysis of London lists of 1695 by David Glass, who found that, even in the late seventeenth century, servants and apprentices were not "entirely distinct categories." ${ }^{35}$ Furthermore, the Middle English Dictionary (MED) has many possible meanings for servaunt, including "an apprentice; an assistant to a surgeon." The evidence suggests William Gale (1) was an apprentice to Thomas Gale (1), a Richard Gale (admitted 1588) was an apprentice to William Gale (1), and finally, William's sons Thomas (2) and John are also connected with the Company of Barber-Surgeons. ${ }^{36}$ Does this pattern also signify a familial rela-

33 Patrick Wallis, "Apprenticeship and Training in Premodern England" in The Nature of Evidence: How Well Do Facts Travel?, ed. Jon Adams, London School of Economics 22, no. 7 (2007): 14, http://www.lse.ac.uk/economicHistory/pdf/FACTSPDF/2207Wallis.pdf, accessed 5 March 2016; Douglas Hay and Paul Craven, eds., Masters, Servants, and Magistrates in Britain and the Empire, 1562-1955 (Chapel Hill: University of North Carolina Press, 2004), 63-69. 34 Jonathan Barry, The Tudor and Stuart Town, 1530-1688: A Reader in English Urban History (Oxford: Routledge, 1990), 106.

35 Barry, Tudor and Stuart Town, 106.

36 Guildhall Library MS 5265/1; Robinson, “St Thomas's Hospital Surgeons,” 418. 
tionship between Thomas (1) and William (1), or is it a coincidence of common names?

It is possible that William Gale (1) relocated from Yorkshire to the capital in his teens (1550s) to serve his apprenticeship. The pedigree for Gale of Hadley from Harleian MS 1551 (fol. 55) shows that a William Gale (3) of Carthorpe, Burneston, Yorkshire, is the father of William Gale (1), who was born in Carthorpe and buried in Monken Hadley. ${ }^{37}$ Several of William Gale's (1) children are shown to be born in Monken Hadley, including John Gale (who later settled in Bushey). Furthermore, a list of Blanche Parry's Yorkshire tenants in 1551 shows a William Gale (possibly William's [1] father) as a tenant in the Wheldrake lands, Yorkshire; there are no Gales present on a similar list compiled in $1567 .{ }^{38}$ The death date, siblings, and other activities of William (3) are not known. Migration from the provinces to London to train as an apprentice, especially under a relative, was not unusual in the sixteenth century. Ian D. Whyte in his analysis of migration in Britain from 1550 to 1830 remarked that most people moved to London in their teens or twenties and that literate people were more likely to move farther than their illiterate counterparts. ${ }^{39}$ This statement coincides with the profile of William Gale (1), who wrote his name in Latin and Greek in Ashmole 1505, and who would have been around eleven to thirteen years old at the time of the 1551 tenant list, and then in his mid-twenties at his admittance to the London Company of Barber-Surgeons (1566). Some estimates suggest that one million people migrated to London between 1550 and 1750,

37 Frederick Charles Cass, Monken Hadley (Westminster: J. B. Nichols and Sons, 1880), 161, www.archive.org, accessed February 2016; George J. Armytage, ed., Middlesex Pedigrees, as Collected by Richard Mundy in Harleian MS. No. 1551 (London: Mitchell, Hughes and Clarke, 1914), 77-78, www.archive.org, accessed March 2016.

38 Ruth Elizabeth Richardson, "Blanche's Yorkshire Tenants/Fieldnames” (2008), http:// www.blancheparry.co.uk/articles/papers/blanches_yorkshire_tenants.pdf, accessed February 2016; Ruth Elizabeth Richardson, Mistress Blanche Queen Elizabeth I's Confidante (Herefordshire: Logaston Press, 2007), 121-24.

39 Ian D. Whyte, Migration and Society in Britain, 1550-1830 (Hampshire: Palgrave Macmillan, 1999), 70-72. 
and one analysis of data from the early seventeenth century shows that onethird to a half of the immigrant population in London were apprentices. ${ }^{40}$

Determining if the brother "William" mentioned by Thomas (1) in his will is synonymous with the father, William (3), of Thomas's apprentice William (1) is challenging due to the lack of primary records. Most secondary sources, including the Oxford Dictionary of National Biography, state that Thomas Gale (1) was born in London circa 1507.41 Unfortunately, London parish baptismal records are not available to confirm this (1538 is the earliest available date), and no siblings or parents for William Gale (3) are accounted for in the Gale pedigree in the Harleian manuscript or the Gale pedigree rolls held by the Society of Genealogists Library or the Burneston records held by the North Yorkshire County Record Office (which start from 1566). Without further documentary evidence, the exact relationship beyond master and apprentice between Thomas (1) and William (1) cannot be known, but informed speculation would suggest an uncle/ nephew relationship or at least a distant familial connection. For clarity, figure 6 shows a partial family tree of individuals relevant to this article's enquiry. ${ }^{42}$

The final person mentioned by name in the manuscript is in reference to the marriage of a Blanche May in 1567 followed by the initials W. G. (figure 3). A search of all available parish records, including, but not limited to, Burneston, London, and Monken Hadley, between 1566 and 1590, has revealed no hits for this name or date of marriage. However, if the Gales

40 John Wareing, "Migration to London and Transatlantic Emigration of Indentured Servants, 1683-1775," Journal of Historical Geography 7, no. 4 (1981): 356-78, quoted in Whyte, Migration and Society in Britain, 71; Jeremy Boulton, Neigbbourbood and Society: A London Suburb in the Seventeenth Century (Cambridge: Cambridge University Press, 1987), quoted in Whyte, Migration and Society in Britain, 72.

41 Max Satchell, “Thomas Gale (c. 1507-1567), surgeon,” in Oxford Dictionary of National Biography (2008), http://www.oxforddnb.com/view/article/10297?docPos=1, accessed February 2016.

42 See the Gale pedigree in Armytage, Middlesex Pedigrees, 77-78, and Gayle N. Mandell, “The Gale \& Gayle Families," www.gale-gaylefamilies.com, for more details on other individuals connected with the Gale surname. 
Manuscript Studies, Vol. 2 [2018], Iss. 2, Art. 4

Connelly, "My Written Books of Surgery in the Englishe Tonge" | 383

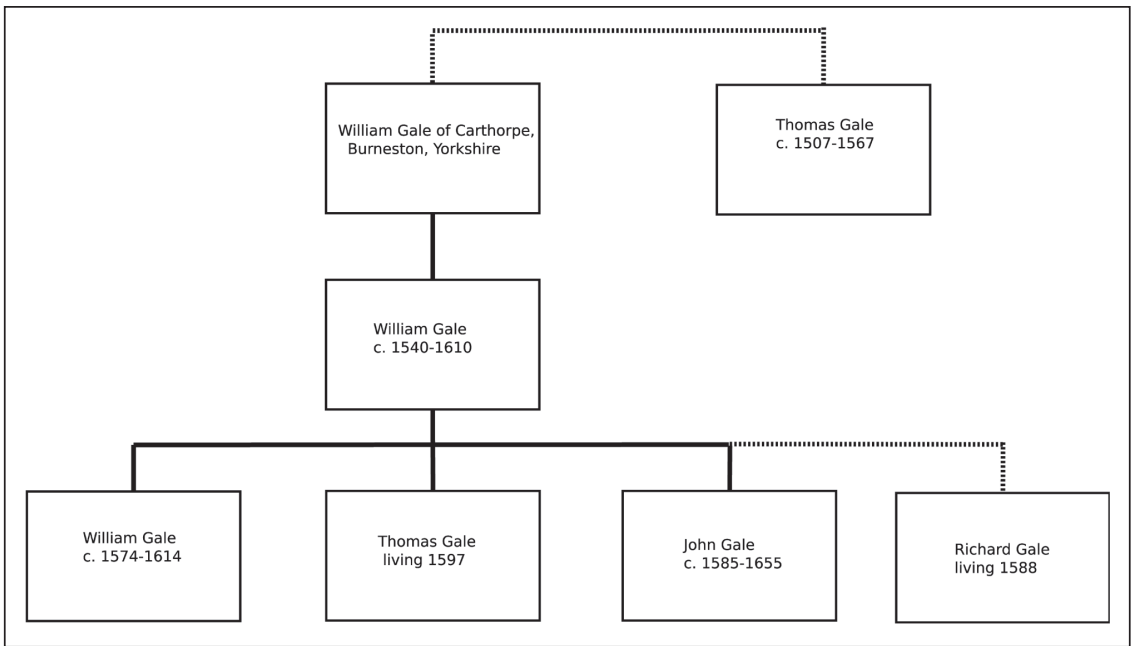

FIGURE 6. Gale family tree.

were connected to the lands of Blanche Parry, perhaps the name "Blanche May" belongs to a sister of William Gale (1). Finally, the significance of the date of 1578, which is written at the top of folios $1 \mathrm{v}$ and $245 \mathrm{r}$, has not been possible to determine with finality, as it does not coincide with any significant dates for William Gale (1) in the records. He was married twice: first to Elizabeth and then Susanna (also Suzan), who is mentioned in his will. The recording of marriages has a precedent in this book, so perhaps 1578 is the date of a marriage (the Burneston records do not have entries for this date, and the marriage records for Monken Hadley are not available before 1619). The date could also be the acquisition date of the book, as the evidence does not definitively prove that William Gale (1) inherited the book rather than bought it.

One final note: Thomas Gale (1) does not explicitly name the Lylye of Medicynes in his will, as John Wisdom did; he only states, "written books of surgery in Englishe." However, based on the nature of the inscription of William Gale's (1) name in Ashmole 1505, and the surrounding context of documentary evidence containing references to Gales in the Company of Barber-Surgeons, as well as the features of the text that may have been relevant to sixteenth-century barber-surgeons (discussed below), it seems 
Connelly: "My Written Books of Surgery in the Englishe Tonge": The London C

384 | Journal For Manuscript Studies

reasonable to draw a link between Ashmole 1505 and the sixteenth-century Gales of the London Company of Barber-Surgeons.

Relevance of the Lylye of Medicynes

As discussed previously, the contemporary practitioners Thomas Gale (1) and John Wisdom specifically mentioned their medical texts "in English" in their wills; John Wisdom cited the Lylye of Medicynes by name. ${ }^{43}$ It is noteworthy that a copy (or copies) of the Lilium medicinae "in English" was circulating around various groups of medical practitioners in sixteenthcentury London. Furthermore, the specific transmission of these medical manuscripts via wills from one generation of medical practitioners to the next may indicate that the texts had an appeal beyond that of a personal or prestige object. The following will consider how the fifteenth-century Lylye of Medicynes may have had relevance to the activities of the Gale barbersurgeons based on Thomas Gale's production of English medical texts, his motivation to regulate the discipline of surgery, and marginalia by later hands in MS Ashmole 1505, specifically in regard to the treatment of visual impairments.

The accessibility of medical materials for non-Latinate practitioners was a particular concern of Thomas Gale's throughout his life. He is responsible for an English translation of Galen; furthermore, he defines his target audience as "prentises and young men, which haue not beene trained vp in schooles, neither yet can vnderstand the Greeke or Latine tongue." ${ }^{34}$ In his Certaine Workes of Chirurgerie, Gale describes his plans to write an herbal text with all the different names attributed to botanical ingredients, including the English names, for increased clarity and accessibility. ${ }^{45}$ In his Antidotarie, Gale states that his chief aim in presenting medicines in Latin within an English text was to provide a greater understanding of the disci-

43 All further references to "Thomas Gale" in this section are to Thomas Gale (1).

44 Quoted in Pahta et al., "Communicating Galen's Methodus medendi," 182.

45 Gale, Certaine Workes of Chirurgerie (Enchiridion), fol. 57v. 
pline for monolingual students. ${ }^{46}$ As an aside, it is interesting that with so much concern expressed by Thomas Gale to prepare "Englyshed" texts, his apprentice, William (1), identifies himself in the opening folio of an English translation using Latin and Greek forms (fols. 1v, 2r). Thomas Gale's desire to standardize terminology and increase accessibility to surgical texts complements his determination to standardize the discipline of surgery.

The union of the barbers and surgeons by an act of Parliament in 1540 restricted barbers to haircutting, shaving, and bloodletting, while surgeons performed all other surgical procedures (both professions administered tooth extractions). ${ }^{47}$ The desire to regulate and control the activities of practitioners is mentioned throughout Thomas Gale's major work, Certaine Workes of Chirurgerie. He identifies two things that have brought surgery to "extreme decaye and ruine": "euery person good and badde, learned and vnlearned, chirurgian or no chirurgian, doe wythout penaltie and correction of lawes frelye take on them the practise of chirurgerie. The other thyng is, that the chirurgians them selues . . . are vnworthye professours." ${ }^{8}$ It is worth returning at this point to the possible association of Thomas and William (1) Gale with Gregory Wisdom. In the study of Gregory Wisdom's life, The Sorcerer's Tale, Alec Ryrie presents evidence of Wisdom's activities with black magic, the occult, criminality, and use of magic to defraud patients. As discussed above, Gregory and his father John were unlicensed practitioners who were granted a royal license after being sued for illicit activities. Ryrie states that Gregory Wisdom used his legitimate status, and contacts in the criminal underworld, to exploit and defraud patients; upon review of his career, Ryrie sums up Wisdom as "a trickster, a liar, and a thief." ${ }^{49}$ Also of note, a Richard Gyle is listed as a witness to Gregory Wisdom's will (1599). ${ }^{50}$ This may be the surgeon Richard Gyle who confessed to

46 Gale, Certaine Workes of Chirurgerie (Antidotarie), preface.

47 Elizabeth Lane Furdall, The Royal Doctors, 1485-1714: Medical Personnel at the Tudor and Stuart Courts (Rochester, NY: University of Rochester Press, 2001), 10; see also "History of the Company," Worshipful Company of Barbers, www.barberscompany.org.

48 Gale, Certaine Workes of Chirurgerie, preface.

49 Ryrie, The Sorcerer's Tale, 109, 183.

50 London Metropolitan Archives, Guildhall Library Register of Wills, MS 9051/5, fol. 141r. 
and was found guilty of medical negligence in the censorial hearings of 1602 and 1605. ${ }^{51}$ Ryrie suggests it could be the same Gyle who fought the first court case against the Royal College of Physicians under the Quacks' Charter in $1545 .{ }^{52}$ Overall, Gregory Wisdom appears to be the diametric opposite to the professionalism advocated by Thomas Gale in his works. In Gale's perspective, perhaps Wisdom is the type of "vnworthye professour" that required better regulation. There is evidence of conflicting worldviews at work here, perhaps suggesting the men would not be close connections, but that does not necessarily preclude the transfer of the Lylye of Medicynes from Wisdom to Thomas Gale (or William [1]). Turning aside from the route of ownership, the Lylye's attitude toward surgeons may have resonated with later practitioners who shared Thomas Gale's perspective.

Thomas Gale's sixteenth-century frustration with the proliferation of untrained surgeons, and their threat to patients, hearkens back to medieval complaints of the same nature. Bernard of Gordon completed the Lilium medicinae at the same time that Henri de Mondeville, royal surgeon to Philip the Fair and visiting lecturer in the medical school at Montpellier, was writing his treatise on surgery. ${ }^{53}$ Mondeville, a highly educated and respected surgeon, gives his opinion of the contemporary state of surgery in the introduction to his treatise: "I do not see any surgeon among my contemporaries who is inclined to study; very few of them are lettered." Furthermore, he states, "surgery . . . is above all a theoretical science, and this aspect of it cannot be mastered by any mere layman." ${ }^{4}$ The same sentiment was voiced in a Middle English translation of Lanfranc's major surgical treatise, which speaks of "manye lewid lechis" attempting to perform surgi-

51 Margaret Pelling and Frances White, "Gyle, Richard," in Physicians and Irregular Medical Practitioners in London 1550-1640 Database (London: Centre for Metropolitan History, 2004), http://www.british-history.ac.uk/no-series/london-physicians/1550-1640/gyle-richard-2, accessed 5 March 2016.

52 Ryrie, The Sorcerer's Tale, 52.

53 Marie-Christine Pouchelle, The Body and Surgery in the Middle Ages, trans. Rosemary Morris (Cambridge: Cambridge University Press, 1990), 2, 5.

54 Both quotes are from Pouchelle, Body and Surgery, 15. 
cal procedures beyond their skill level. ${ }^{55}$ Similarly, a fifteenth-century Middle English translation of John Arderne's Fistula in Ano records an incident of an unskilled surgeon who "deceyued many men" in trying to cure fistulas. ${ }^{56}$ Arderne is an example of a surgeon who was not universitytrained, but who still developed a reputable practice. The Middle English Lylye expresses similar reservations to surgical treatment. Surgeons are recommended specifically for fistula in ano, but, for the most part, they are mentioned as the last resort in conditions resisting more conservative treatments. For instance, in treating gangrene, the Lylye states that it is better to treat the dead flesh with medicine or cauterization than it is to treat it with cutting (fol. 27r). The Lylye mentions two cases where surgeons caused injury to patients by cutting away too much flesh in attempting to treat tumors and fistula in the eyes (fol. 99). The text states that for cases of surgical accidents, there is no cure (fol. 99r). In the treatment of hemorrhoids, the text concludes that surgeons for the most part are unskilled (fol. 214r). The text also states that care should be taken when choosing a surgeon and to be certain that he is university-trained, understands anatomy and the properties of medicines, and is "yletteryd and expert" (fols. 39v, 99, $104 \mathrm{v}-105 \mathrm{r}, 214 \mathrm{r}$; fol. 98r). In the Lylye, the physician is expected to know how to perform bloodletting, incisions, sewing of wounds, setting of bones, cupping, cauterization, and couching and to only turn to surgeons for particular disorders (fistula in ano) or as a last option. Beyond the shared problem of unregulated practice in the medieval and early modern periods, medical practitioners often shared the same model of disease (humoral theory) and the same authoritative texts (namely, translations of Ibn Sīnā, Galen, and Hippocrates). When considering the period between the early fourteenth century, when the Lilium medicinae was written, the early fifteenth century, when it was translated into Middle English (Lylye of Medicynes), and

55 Robert von Fleischhacker, ed., Lanfrank's Science of Cirurgie, EETS 102 (London: K. Paul, Trench, Trübner \& Co., 1894; rept. Millwood, NY: Kraus, 1988), 292.

56 D'arcy Power, ed., Treatises of Fistula in Ano, Haemorrhoids, and Clysters by John Arderne from an Early Fifteenth-Century Manuscript Translation, EETS Original Series 139 (1910; rept. London: EETS, 1968), 3. 
the sixteenth century, when it circulated among practitioners, medical innovation, drug development, and changes to the treatment process hardly moved from an established set of practices preserved from authorities of the past.

Considering that humoral theory was the dominant belief system among medical practitioners from Hippocrates through to the late nineteenth century, rapid development and overturning of established paradigms, so integral to present-day medicine, have not been the key forces of medical practice for much of history. ${ }^{57}$ It would be overly simplistic to suggest that medicine from the early fourteenth century to the early seventeenth century was static, but, in general, the prevailing attitude was one of preservation, or "gathering together," the ideas of accepted authorities, rather than one of innovation. For instance, the introduction to the Middle English Lylye of Medicynes states its purpose as: "we wollep gadre to gedre truely pe exposiciouns of Galen and Ypocras and Auicen and of mo oper" (fol. 4v). This statement is similar to that of Thomas Gale's in his Institution of Chirurgerie, where he identifies "Hippocrates, Galene and Auicenne" (among others) as authorities of "sounde doctrine." 58 Furthermore, the Lylye of Medicynes refers to Galen as "pe prinse of leches" (fol. 5r), which is also stated by Thomas Gale in reference to Hippocrates and Galen as the "princes of phisicke. ${ }^{59} \mathrm{He}$ also mentions that "Master Doctour Cunyngham" read the "booke of Galen of tumours" to the barber-surgeons at their hall in London. ${ }^{60}$ These references are more than a dutiful recognition of the authorities of the past, as evidenced by the medicinal recipes attributed to Galen (and others), which are included for practical use in Gale's Antidotarie.

The ingredients used in the recipes of the Lylye of Medicynes and Thomas Gale's Certaine Workes of Chirurgerie are similar, even though they are sepa-

57 Certainly there were individuals that questioned humoral theory, such as Andreas Vesalius's De bumani corporis fabrica (1543), Helkiah Crooke's Mikrokosmographia (1615), William Harvey's De motu cordis (1628), but it was the optical refinement of the microscope and isolation of disease-causing agents in the laboratory from the late nineteenth century onward that disproved humoral theory with finality; see also Deborah Lupton, Medicine as Culture: Illness, Disease, and the Body in Western Societies (London: Sage, 1994), 83.

58 Gale, Certaine Workes of Chirurgerie (Institution of Chirurgerie), fol. 2r.

59 Gale, Certaine Workes of Chirurgerie (Institution of Chirurgerie), fol. 3v.

60 Gale, Certaine Workes of Chirurgerie (Institution of Chirurgerie), fol. 19r. 
rated by more than a century. In the Lylye, the greatest anatomical description is reserved for the eyes. The anatomy is derived from Galen; nevertheless, early writers attributed a particular acumen for ophthalmology to Bernard, crediting him as one of the first doctors to mention eyeglasses. ${ }^{61}$ The Lylye is largely devoid of marginalia by readers, except for the section on eyes. In the chapter Fistula in lacrimali (fol. 99r), a number of glosses by a later reader are present, while the chapter titled "weakness of sight" (De debilitate visus) contains the following comments from a later reader: "thyngis anoyous for the sighte" (fol. 105r), "a good water for eyen" (fol. 106r), and "a specyall wa[ter] for eyen" (fol. 106v). "A good water for eyen" is written in the margin by a later hand next to the following recipe in the same chapter concerning the restoration of sight (Curacio particularis debilitatis visus et potissime cum oculi videntur sani et visus debilitatur):

Make hym pis watere and euery day he schal do perof in his yzen as ofte as he wole: Rx celidonie, feniculi, rute, sileris montani, eufrasie, veruene, rosarum rubearum ana libra $\beta$, gariofilum, piperis longi ana $\zeta \mathrm{ij}$. Breke hem and put hem in a stillatorie of glas and make a lent fuyre and make perof water as men dop of rosis and kepe hyt. (fol. 106r)

Compare the recipe above with this recipe from Thomas Gale's section on cures for the restoration of sight in his Enchiridion:

Rece. Aquarum feniculi, rosarum, polij, eufragie, rute, ana halfe vnce, albuminum ouorum q.s. [quantum sufficit]. These bid he temper and myxe togyther and applied it to the eie. ${ }^{62}$

Gale states that his recipe comes from "Brunswycke" (Jerome); however, it is possible that he was the one to recognize the similarity in these recipes via the marginal comment in the Lylye.

61 Edward Rosen, "The Invention of Eyeglasses," Journal of the History of Medicine and Allied Sciences (1956): 201-2, http://jhmas.oxfordjournals.org.

62 Gale, Certaine Workes of Chirurgerie (Enchiridion), fol. 19v. 
The reference to eyeglasses is found in the same section (weakness of sight) as these marginal comments in a statement about the efficacy of a particular recipe for eyedrops. In the Middle English it is rendered as, " $p$ is is so grete of vertue pat it makip elde men rede smal lettre wipout any spectacle" (fol. 107r), while in the 1497 (Venice) Latin incunabulum of the Lilium medicinae (and the 1559 [Lyon] printed edition), spectacle is given as ocularibus. The MED defines spectacle as "a device for assisting or enhancing the vision, a lens, an eyeglass." Manuscripts of the Lilium medicinae from the fourteenth century differ from later printed editions in that such forms as oculo berellino or oculo de berillino are employed instead of ocularibus. ${ }^{63}$ This discrepancy led Edward Rosen to question Bernard's prescience in the development of eyeglasses and to attribute the reference to later editors of the Lilium medicinae rather than to Bernard. ${ }^{64}$ Magnifying lenses for reading made of beryl (or quartz or another translucent precious stone) are also referenced by Guy de Chauliac in Chirurgia Magna, as well as by earlier authors such as Roger Bacon and Robert Grosseteste. ${ }^{65}$ Bernard may have been referencing a type of magnifying glass made of beryl rather than eyeglasses in the modern conception of the term. In summary, the concentration of glosses and comments in the eye section of the Lylye and similarity in ingredients used in the Lylye and Thomas Gale's work suggest that the Lylye could have had relevance to the members of the Company of BarberSurgeons beyond that of a prestige or ceremonial object.

\section{Conclusion}

Many conclusions may be drawn from quite an open-ended enquiry into the four individuals whose names are inscribed in the Lylye of Medicynes. Previous scholarship has revealed many facets of the two early owners, Robert

63 Respectively, British Library MS Sloane 512 (fol. 107r) and British Library MS Harley 3698 (fol. 40r), and British Library MS Sloane 334 (fol. 78r).

64 Rosen, "The Invention of Eyeglasses," 201-2.

65 G. ten Doesschate, "Some Historical Notes on Spectacles and on Beryllus," British Journal of Ophthalmology 30, no. 11 (1946): 660-64. 
Manuscript Studies, Vol. 2 [2018], Iss. 2, Art. 4

Broke and Richard Cler, and the examination of documentary evidence in this article indicates a significant correlation with the Gale family of barbersurgeons in sixteenth-century London. Although all aspects of their relationships and activities may never be fully known without additional documentation, it is possible that the manuscript was transferred from Cler's ownership to that of Thomas Gale (potentially through Gregory Wisdom), then to the "expert surgeon" William Gale, identified in folio 1v (possibly to one of William's sons), before entering Elias Ashmole's collection. There are interesting questions, worth exploring in greater detail, about the relationship between Broke (the king's distiller), the practical text of the Lylye, and the treatment of Henry VI. This brief examination also suggests some intriguing questions about the transmission and circulation of medieval medical texts and their practical value for later practitioners.

\section{Acknowledgments}

Research for this article has been assisted by The Barbers' Company (Victoria West), the Bodleian Library, Gayle N. Mandell, the Guildhall Library, Herefordshire Archives and Records Centre, North Yorkshire County Record Office, St. James Church (Bushey), St. Mary the Virgin (Monken Hadley), and the Society of Genealogists Library. Thank you also to Dr. Christina Lee and Dr. Nicola Royan, who read early drafts of this article. 


\section{List OF MANUSCRIPTS CiTED}

Baltimore, Walters Art Museum

W 751: 451, 470

W 759-62: 474

W 777: 473

Bangkok, Wat Hua Krabu

Manuscript: 431, 432 fig. 1

Berlin, Staatsbibliothek

HS 241: 480

Birmingham, Barber Institute

No. 397: 479

Boston, Boston Public Library

MS 1532: 473

Brussels, Bibliothèque Royale

MS IV 191: 481

MS IV 542: 478

Bryn Mawr, PA, Bryn Mawr College

Gordan MS 95: 527-28, 527 fig. 1, 528

nn. 15-16

Cambridge, MA, Harvard University,

Houghton Library

MS Richardson 17: 482

MS Richardson 26: 471

MS Typ 141: 476

MS Typ 143: 480

MS Typ 200: 472

MS Typ 201: 474

MS Typ 202: 472

MS Typ 213: 478

MS Typ 217: 482

MS Typ 228: 474

MS Typ 703: 476
Cambridge, UK, Corpus Christi College

MS 4: 585

MS 32: 338, 338 n. 25, 343 n. 34, 355 n. 61

Cambridge, UK, Fitzwilliam Museum

MS 251, fol. 15r: 585

MS 276: 586

MS 159: 587

MS 330: 472, 585

MS 375: 462, 478

Collegeville, MN, Saint John's University,

Ethiopian Manuscript Microfilm Library

MS no. 4553: 414 n. 69

Cologne, Historisches Archiv

Best. 7010-293: 585

Cologny, Fondation Martin Bodmer

Cod. Bodmer $14: 476$

Cod. Bodmer 68: 470

Cod. Bodmer 104: 480

Cod. Bodmer 128: 481

Cod. Bodmer 139: 481

Cod. Bodmer 183: 474

Dublin, Chester Beatty Library

Thai MS 1341: 432

Thai MS 1343: 433

W 017: 471

W 029: 471

W 040: 472

W 043: 472

W 061: 474

W 066: 474

W 076: 457 fig. 3, 475

W 078: 475 
Manuscript Studies, Vol. 2 [2018], Iss. 2, Art. 4

\section{Journal for Manuscript Studies}

W 080: 475

W 082: 453, 454 fig. 1, 458, 479

W 089: 478

W 094: 479

W 099: 482

W 107: 477

W 108: 477

W 113: 477

W 122: 477

W 124: 476

W 127: 476

W 188: 480

W MS 103 (formerly; now dismembered): 455 fig. 2, 456

Dunhuang

Nai 93: 499, 502-7, 503 n. 8

Tama 24: 499, 502-7, 503 n. 8

Florence, Bibl. Medicea Laurenziana

MS Or. 148: 423

Geneva, Bibliothèque de Genève

Comites Latentes MS 15: 474

Comites Latentes MS 38: 479

Ghent, Universiteitbibliotheek

MS 92: 569

Göttingen, Niedersächsische Staatsund-Universitätsbibliothek

MS Uffenb. 51 cim.: 585

The Hague, Koninklijke Bibliotheek

MS 135 E 23: 478

MS 135 J 8: 477

The Hague, Museum Meermanno-

Westreenianum

MS 10 B 23: 355 n. 61

Hildesheim, Dombibliothek

MS St Godehard 1: 355 n. 61

Jerusalem, National Library of Israel

Yah MS Var 4: 467 n. 96, 478

Yah MS Var 8: 467 n. 96, 477

Yah MS Var 9: 467 n. 96, 478
Yah MS Var 11: 467 n. 96, 477

Yah MS Var 12: 467 n. 96, 482

Yah MS Var 13: 475, 467 n. 96

Yah MS Var 14-15: 476, 467 n. 96

Yah MS Var 16: 467 n. 96, 481

Kew, The National Archives

PROB 11/49/251: 375 n. 15-16, 378 n. 31

PROB 11/116/532: 377 n. 24

Lichfield, Cathedral Library

MS 1: 483-98

Lisbon, Museu Calouste Gulbenkian MS LA 210: 479

London, British Library

Add. 38662: 296-327, 296 n. 1, 299 fig. 1, 306 n. 26

Add. 38663: 296-327, 296 n. 1, 299 fig. 2, 306 n. 26

Add. 38664: 296 n. 1

Add. 40142: 296-327, 296 n. 1, 301 fig. 3, 306 n. 26

Add. 40143: 296 n. 1

Add. MS 43460: 469

Add. MS 48985: 474

Add MS 52660: 452 n. 33-34, 462 n. 70, 466 n. 90-91

Add. MS 52653: 446 n. 6, 447 n. 7, 449 n. 16-17

Add. MS 52656: 458 n. 51

Add. MS 52657: 458 n. 49, 472 n. 99, 476

n. 106

Add. MS 52658: 452 n. 31

Add. MS 52662: 459 n. 55, 461 n. 67, 462

n. 68

Add. MS 52670: 460 n. 58, 462 n. 72 and 75

Add. MS 52692: 462 n. 73

Add. MS 53652: 445 n. 1

Cotton MS Nero A XI: 311

Egerton MS 3055: 472

Egerton MS 3088: 473

Egerton MS 3089: 471 
MS Harley 1862: 335 n. 23

MS. Harley 3698: 390 n. 63

MS Harley 3915: 585

MS Laud Misc. 511: 336 n. 24, 347

MS Royal 15 D 1: 355 n. 61

MS Royal 17: 328 n. 1

MS Royal 17 C.xxxiii (Royal C): $328 \mathrm{n}$.

1, 333, 335-36, 336 fig. 1, 346 n. 37, 365

n. 67

MS Royal 17 D.viii (Royal D): 333, 335-

37, 337 fig. 2, 346 n. 37, 348 n. 46, 349

n. 47,352 n. 50,365 n. 67

MS. Sloane 334: 390 n. 63

MS. Sloane 512: 390 n. 63

OR. 13703: 433, 434 fig. 2

Or. 16552: 434

Yates Thompson MS 7: 450 n. 19

London, London Metropolitan Archives, Guildhall Library

MS. 5265/1: 376 n. 17, 377 n. 25, 380 n. 36

MS. $9051 / 5$ : 378 n. 30,385 n. 50

MS. $9171 / 15: 378$ n. 28

London, Quaritch Archives

Commission Book for 1914-1917: 446

n. 2-3

Commission Book for 1917-1920: 450

n. 19 and 21

Commission Book for 1921-1926: 461

n. $62-63$

London, Victoria and Albert Museum

MS 16: 472

MS Ludwig V 6: 475

MS Ludwig IX 3.: 474

P.159-1910: 585

Los Angeles, The J. Paul Getty Museum MS 48: 478

MS Ludwig XI, 1: 480

Madrid, Biblioteca Nacional

MSS/11267/21: 542
Milan, Biblioteca Nazionale Braidense

AC IX 36: 473

Monza, Biblioteca Capitolare

Monza a-3/10: 514 n. 24

Monza a-3: 513 n. 18, 514, 514 n. 21, 515 n. 27

Monza a-4: 513 n. 18

Monza a-5: 513 n. 18, 515 n. 29

Monza a-6: 513 n. 19, 516 n. 30, 518-19

Monza a-7: 513 n. 19

Monza a-8: 513 n. 18

Monza a-9: 513 n. 19

Monza a-10: 513 n. 19, 514 n. 20, 516

n. 31,517 fig. 2

Monza a-11: 513 n. 19, 516 n. 31

Monza a-12: 513 n. 18

Monza a-13: 513 n. 19, 516 n. 31

Monza a-14: 513 n. $18-19,516$ n. 31

Monza a-15: 513 n. 17

Monza a-16: 513 n. 19, 516 n. 32

Monza a-17: 513 n. 19, 516 n. 31

Monza a-18: 513 n. 19, 516 n. 32

Monza a-19: 513 n. 19

Monza a-20: 513 n. 18

Monza a-21: 513 n. 18

Monza a-22: 513 n. 18, 514 n. 24, 515 n.

27, 516 n. 30, 519

Monza a-23: 513 n. 19, 514 n. 24, 515

n. 27

Monza a-24: 513 n. 18

Monza a-25: 513 n. 18, 514 n. 24, 515

n. 27

Monza a-26: 513 n. 19

Monza a-27: 513 n. 16

Monza b-1: 513 n. 16

Monza b-2: 513 n. 19, 516 n. 31

Monza b-3: 513 n. 19, 515, 515 n. 25

Monza b-4: 513 n. 19, 515, 515 n. 28

Monza b-5: 513 n. 19, 514 n. 24, 515

n. 27

Monza b-7: 513 n. 16

Monza b-9: 514 n. 24, 515 n. 27

Monza e-4: 513 n. 18, 516 n. 31 
Manuscript Studies, Vol. 2 [2018], Iss. 2, Art. 4

\section{Journal for Manuscript Studies}

Monza e-5: 513 n. 18

Monza e-6: 513 n. 17 and 19

Monza e-8: 513 n. 19

Monza e-9: 513 n. 16

Monza e-11: 513 n. 18

Monza e-13: 513 n. 19, 516 n. 31, 519

Monza i-11: 513 n. 17

Münster, Bibliothek Universität Münster

MS NR 1003: 481

New Haven, Yale University, Beinecke Rare

Book and Manuscript Library

MS 111: 480

MS 400: 449, 449 n. 18, 479

MS 402: 471

MS 407: 475

MS 413: 470

MS 414: 472

MS Osborn fa42: 472

New York, Metropolitan Museum of Art 1997.320: 473

New York, Morgan Library and Museum ARC 1310: 458 n. 50, 463 n. 78

MS G 17: 471

MS M 777: 450 n. 21, 471

MS M 808: 473

MS M 826: 469

MS M 855: 473

MS M 860: 470

MS M 862: 470

MS M 883: 471

MS M 939: 472

MS M 962: 471

New York, New York Public Library

MS M 834: 479

MS M 1004: 479

MS M 1110: 479

Spencer MS 27: 451, 480-81

Spencer MS 28: 480

Spencer MS 29: 477

Spencer MS 64: 481

Thai MS.6: 432
Oslo, Schøyen Collection

MS 50: 470-71

Oxford, Bodleian Library

Digby 23: 322, 322-23 n. 87

MS 48: 326 n. 100

MS. Ashmole 1505: 369-91, 371 fig. 1, 272 fig. 2, 373 figs. 3-4, 374 fig. 5

MS Bodley 978: 328-68, 328 n. 1, 341 n. 33, 342 fig. 3, 343 fig. 4, 344 fig. 5, 346 n. 37, 347 n. 43, 348 n. 46, 349 fig. 6, 349 n. $47-48,352$ n. $50-51,353$ n. 55, 357 fig. 7 , 358 n. 64,361 fig. 8,361 n. 67,362 n. 68 , 366 n. 78,368 n. 80

MS Pali a.27 (R): 428 n. 3, 431, 444 MS Phillipps-Robinson C 719: $450 \mathrm{n}$. 22-24, 451 n. 25-26 and 29, 458 n. 47, 459 n. $53-54$

Oxford, Lincoln College

MS Lat. 150: 473

Oxford, Trinity College

MS 93: 332 n. 14, 583

Oxford, Worcester College

MS E. 10. 7: 583

Paris, Bibliothèque nationale de France MS Éth. 35: 415 n. 71

MS fr. 24766: 300, 300-301 n. 7, 302 fig. 4, 304-5, 309

MSS n.a.f. 15939-15944: 475

MS n. a. lat. 3115: 478

MS n. a. lat. 3119: 480

Paris, l'École française d'Extrême-Orient EFEO 39: 434, 435 fig. 3

EFEO 40: 432

Phillipps, Sir Thomas, collection of MS 125: 474

MS 134/3948: 475

MS 137: 480

MS 240: 477

MS 250: 480

MS 385: 472 


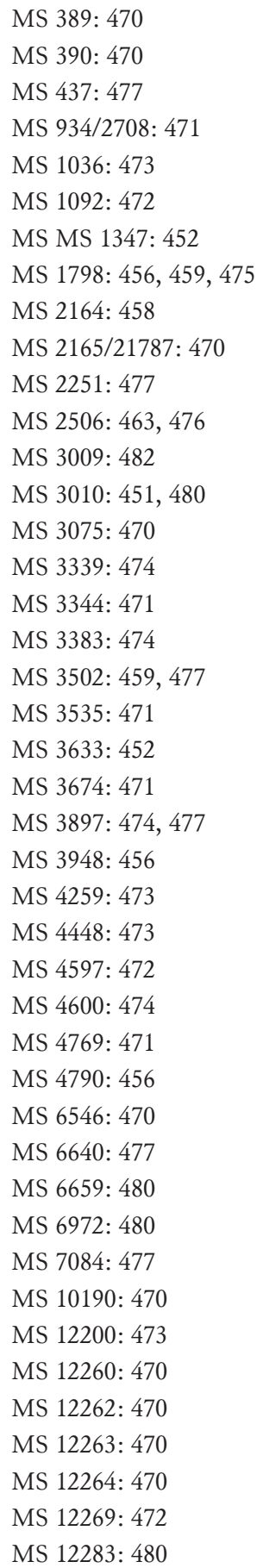

MS 12348: 471

MS 14122: 451, 470

MS 21948: 471

Private Archive of the Escalante family Historia de los reyes moros de Granada: 544-67, 548 fig. 1,550 n. 18 and 22-23, 551 fig. 2, 551 n. 24,553 fig. 3, 554 fig. 4, 555 fig. 5

Petchaburi, Thailand, Wat Lat

Manuscript: 433

Philadelphia, Philadelphia Museum of Art 1945-65-6: 480

Philadelphia, University of Pennsylvania Rare Book and Manuscript Library MS Codex 730: 528, 530 fig. 3, 531, 531 nn. 20-22, $532 \mathrm{nn} .23-26$ and 30-34, $533 \mathrm{nn} .37-39,41,43-47,49$ and 53, 534 nn. 56-60, 62-63 and 65-73, 535 nn. $74-75,80-82$ and 84,536 n. 85,87 and 90-95, 537 nn. 96-99, 101-2 and 104-113, 538 nn. 119-22, 124-25, 12833 and $135-6,539$ nn. 137-40, 145-50 and 152

MS Codex 741: 528, 529 fig. 2, 531, 531 nn. 20-22, 532 nn. 23-30, 32 and 35, 533 nn. 36, 40, 42, 46-48 and 50-52, $534 \mathrm{nn}$. 54-58, 60-67 and 71, $535 \mathrm{nn} .74-83,536$ nn. 85-90, 93 and 95, $537 \mathrm{nn} .97$ and 99-115, 538 nn. 116-20, 123, 125-27, 129-31 and 133-34, 539 nn. 141-43, 145-46 and 151 Ms. Coll. 591: 509 n. 4, 510 fig. 1

Princeton, Princeton University Library

Kane MS 31: 476

Kane MS 33: 482

Kane MS 43: 480

Kane MS 48: 482

MS Garrett 143: 296 n. 1

Rome, Biblioteca Casanatense

MS 969: 269 
Manuscript Studies, Vol. 2 [2018], Iss. 2, Art. 4

\section{4 | Journal for Manuscript Studies}

MS 1730: 267-95, 267 n. 1, 267-68 n. 3, 268 n. 4, 269 n. 6, 270 fig. 1, 272 figs. 2-3, 273 fig. 4, 277 fig. 5, 277 nn. 17-21, 278 figs. $6-7,279$ n. 22 , 280 figs. $8-9$, 280 n. 23, 281 figs. $10-11,281$ n. 24 , $282 \mathrm{nn} .25-27,283$ figs. 12-14, 284

n. 28,285 figs. $15-16,285$ n. 29,286

n. 30, 287 figs. $17-18,288$ fig. 19,288

n. 31, 289 fig. 20, 290 figs. 21-22, 291

fig. 23, 291 n. 32, 292 fig. 24,293

fig. 25

MS 2206: 421 n. 75

Rome, Biblioteca Nazionale Centrale

VE 1006: 470

VE 1190: 469

VE 1347: 470

VE 1348: 470

VE 1357: 470

VE Sessor 590: 470

San Lorenzo de El Escorial, Real Biblioteca del Monasterio de El Escorial

Y/III/6: 542, 558 n. 31

San Marino, Huntington Library

HM 31151: 471

Siena, Biblioteca Comunale degli Intronati MS D V 13: 405 n. 37, 418, 420 fig. 2

Stockholm, Nationalmuseum

NMB 1960: 479

Stuttgart, Landesbibliothek

Theol. \& Phil. Fol. 341: 472
Tokyo, Senshu University

MS 7: 467, 467 n. 95, 482

Vatican City, Biblioteca Apostolica Vaticana Stamp. Barb. A VIII 18,: 403, 408 n. 51, 420

Vat. et. 1: 400, 400 n. 25, 409-10, $410 \mathrm{n}$. 59, 421 n. 75, 422, 424 fig. 5, 425, 425 n. 81,426

Vat. et. 2: 400, 400 n. 25, 401, 409, 425-26

Vat. et. 5: 407

Vat. et. 10: 425 n. 82

Vat. et. 15: 406, 406 n. 39, 425

Vat. et. 16-18: 425 n. 82

Vat. et. 25 : $406-7$ n. 44,407

Vat. et. 35: 400, 406, 406 nn. 39-40, 409, 409 n. 53, 421, 422 fig. 3, 425 n. 82, 426

Vat. et. 40: 426

Vat. et. 42, 49, 52, and 57: 425 n. 82

Vat. et. 66: 400, 402-6, 406 n. 39, 407 n. 45, 408 n. 51, 409, 411, 418, 419 fig. 1, 423 n. 80,425 n. 82,426

Vat. lat. Ms. 2648: 269

Vat. lat. Ms. 3978: 269

Vat. lat. Ms. 5092: 269

Vat. lat. Ms. 6177: 398 n. 15, 401 n. 29

Vat. lat. Ms. 6178: 398 n. 16

Vaticano Rossiano 865 MS Vat. Ross 865:

400, 400 n. 25, 409, 422, 423 fig. 4, 426

Vatican City, Archivio Segreto Vaticano

AA., Arm. I-XVIII, no. 2953: $395 \mathrm{nn}$.

7-8, 396 nn. 9-10, 397 nn. 13-14, 398

nn. $17-18,404$ n. 34,416 n. 72 